\title{
Corporate Social Responsibility: a critical view from the case study of Samarco's socio environmental tragedy
}

\author{
JULIANA CAMPOS LOPES ${ }^{1}$ \\ JACQUES DEMAJOROVIC ${ }^{1}$ \\ ${ }^{1}$ Centro Universitário Fel, São Paulo - SP, Brazil
}

\begin{abstract}
Corporate Social Responsibility models in the mining industry have often used sustainability reports and practices linked to the model of the Social License to Operate as a way to ensure the legitimacy of its operations. In Brazil, the Samarco case has challenged the implementation of both strategies, after the company, which was considered an example of social responsibility practices in the mining sector, was responsible for one of the worst social environmental tragedies in the country. This research adopts a case study of the Fundão dam collapse, to enhance the contradictions of the Corporate Social Responsibility model that contributed to the tragedy. Data collection included the company's sustainability reports, documents from public agencies, and interviews with the company's stakeholders affected by the tragedy. The data were worked through content analysis. The results show contradictions between the company's documents and the perception of the community about the risks. Corporate Social Responsibility adopted by Samarco prioritized monitoring the perception of image and the company's reputation with its different stakeholders, by reaching a high level of trust between the company and population. However, this strategy, combined with the economic dependence of the municipality, hid the operational risks of the Fundão dam resulting in increased vulnerability of the local community.
\end{abstract}

Keywords: Corporate Social Responsibility. Sustainability report. Social license to operate. Reputation. Vulnerability.

\section{Responsabilidade Social Corporativa: uma visão crítica a partir do estudo de caso da tragédia socioambiental da Samarco}

\section{Resumo}

Modelos de Responsabilidade Social Corporativa no setor de mineração tem usado de forma crescente os relatórios de sustentabilidade e as práticas ligadas ao modelo da Licença Social para Operar como forma de garantir a legitimidade de suas operações. O caso Samarco desafia o uso destas estratégias no país ao possibilitar que a empresa, considerada referência em práticas de responsabilidade social no setor de mineração, também se tornasse responsável por uma das maiores tragédias socioambientais do Brasil. Por meio do estudo de caso do rompimento da Barragem do Fundão, esta pesquisa buscou evidenciar as contradições do modelo Responsabilidade Social Corporativa da empresa que contribuíram para a emergência da tragédia. A coleta de dados incluiu os relatórios de sustentabilidade da empresa, documentos de órgãos públicos e entrevistas com stakeholders da companhia atingidos pela tragédia, sendo estes dados trabalhados a partir da análise de conteúdo. Os resultados indicam as contradições entre as informações disponibilizadas pela empresa e a percepção de riscos da comunidade. O modelo de responsabilidade social corporativa adotado pela Samarco priorizou o monitoramento da percepção da imagem e reputação da empresa junto a seus diferentes stakeholders, favorecendo a construção de laços de confiança com a população. No entanto, esta estratégia, aliada a dependência econômica do município, encobriu os riscos operacionais da barragem do Fundão resultando na ampliação da vulnerabilidade social da comunidade local.

Palavras-chave: Responsabilidade Social Corporativa. Relatórios de sustentabilidade. Licença social para operar. Reputação. Vulnerabilidade.

\section{Responsabilidad Social Corporativa: una visión crítica a partir del estudio de caso de la tragedia socioambiental de Samarco}

\section{Resumen}

Los modelos de responsabilidad social corporativa en la industria minera han utilizado cada vez más informes de sostenibilidad y prácticas vinculadas al modelo de la licencia social para operar como una forma de garantizar la legitimidad de sus operaciones. El caso Samarco desafía el uso de estas estrategias en el país al posibilitar que la empresa, considerada referencia en prácticas de responsabilidad social en el sector minero, también se hiciera responsable de una de las más grandes tragedias socioambientales de Brasil. Por medio del estudio de caso del rompimiento de la represa de Fundão, esta investigación buscó evidenciar las contradicciones del modelo responsabilidad social corporativa de la empresa que contribuyeron al trágico acontecimiento. La recolección de datos incluyó los informes de sostenibilidad de la empresa, documentos de organismos públicos y entrevistas con stakeholders de la compañía afectados por la tragedia, y estos datos se trabajaron a partir del análisis de contenido. Los resultados evidencian contradicciones entre los documentos generados por la empresa y la percepción de riesgos de la comunidad. El modelo de responsabilidad social corporativa de Samarco priorizó el monitoreo de la percepción de la imagen y reputación de la empresa ante sus stakeholders. Sin embargo, esta estrategia, combinada con la dependencia económica del municipio, ocultó los riesgos operacionales de la represa de Fundão, lo que resultó en el aumento de la vulnerabilidad de la comunidad local.

Palabras clave: Responsabilidad social corporativa. Informes de sostenibilidad. Licencia social para operar. Reputación. Vulnerabilidad.

Article submitted on February 09, 2018 and accepted for publication on December 31, 2019

[Translated version] Note: All quotes in English translated by this article's translator].

DOI: http://dx.doi.org/10.1590/1679-395173811x 


\section{INTRODUCTION}

The rupture of the Fundão dam, of Samarco, in the region of Mariana, Minas Gerais, in Brazil, one of the biggest socioenvironmental tragedies caused by the leakage of mining activity waste in history, places the sector as a fundamental element of the construction of the risk society, according to the classic study by Ulrick Beck (2011). For the author, the multiplication of threats of a socio-environmental nature meant that the old industrial society was replaced by the risk society. While the former is characterized by conflicts over the production and distribution of wealth, the second would be based on the conflict between production and risk distribution. Beck (2011) argues that iconic catastrophes of the 1980s, highlighting Bhopal (1984), Chernobyl (1986) and Exxon-Valdez (1989), can no longer be understood as fatalities or unforeseen events, but as something inherent to modernity that shows, above all, the inability of knowledge built in the 20th century to control its deleterious effects, as the most recent episodes like the British Petroleum oil spill in the Gulf of Mexico show (2010), the release of radioactive material in Fukushima (2011), in Japan, and the fire that hit the fuel terminal of the company Ultracargo, of Grupo Ipiranga, in the port of Santos (2015).

Faced with this scenario, there is a process of greater articulation of stakeholders in order to expand the variety of actors in the corporate governance process. The resolution of conflicts over environmental and social impacts, understood as the responsibility of the State and companies, demands collaborative management, through agreements, consensus and public participation (ANSELL and GASH, 2007) also involving civil society (PRNO and SLOCOMBE, 2012). Thus, companies began to operate under constant surveillance by social forces, and the same globalization that expanded economic opportunities also made businesses more vulnerable to the articulated actions of new social actors that came to have a voice with the advent of communication technologies. In this context, corporate social responsibility (CSR) presents a new vision in which businesses are given a political role to act on issues that go beyond the simple generation of wealth. CSR is defined as business practices that ensure benefits for society as a whole and not just for the company itself, often exceeding what the legislation requires (MCWILLIAN and SIEGEL, 2001). In the mining sector, two strategies have been valued in the current CSR models. The first deals with the dissemination of information, through sustainability reports, understood as a communication tool with stakeholders, collaborating for the reputation of organizations. For Jenkins and Yakovleva (2006), there is significant growth in the use of sustainability reports produced by mining companies, although there is also a growing distrust between the information disclosed and its business practices. A second aspect is the use of the social license to operate (SLO) model in CSR practices in various sectors and, specifically, in mining (WILBURN e WILBURN, 2011). The proposal for a SLO is based on the idea that society can give or refuse support to a company and its operations (PRNO, 2013; MOFFAT and ZHANG, 2014), with mining companies needing to move beyond formal obligations (SANTIAGO and DEMAJOROVIC, 2016) from practices that value dialogue, transparency and trust. Such instruments, built in the context of developed countries, have also been adopted in developing countries. Hilson (2012), however, questions the effectiveness of the replication of CSR models in these countries. The authors argues that it is a gray area demanding the advancement of research.

The Samarco case represents a major challenge for CSR practices associated with the use of these instruments in the country. First, because it is the biggest socio-environmental tragedy in the world involving the mining sector (FERNANDES, GOULART, RANIERI et al., 2016); second, due to the fact that the company has occupied a reference position in the mining area with regard to its operational and socio-environmental practices. The company stood out in the sector in relation to its conduct endorsed by different awards well known in the business world, such as "Best and Biggest" (Exame Magazine) and Transparency Trophy, in relation to the disclosure of its accounting information (O ESTADO DE S. PAULO, 2013). In addition, the SLO was an important element of Samarco's strategy. The annual sustainability report highlights that "through conduct based on dialogue and transparency in relations, the company won the social license to operate - an asset that occupies a central place in our Sustainability Model" (SAMARCO, 2014, p. 4). In this context, the research question that guides this study is what factors explain the fragility of the CSR model implemented at Samarco that contributed to the occurrence of the socioenvironmental tragedy. The objective of this study is to highlight the contradictions of the social responsibility model adopted by the company Samarco from the case study of the Fundão dam rupture process. 


\section{Mining activity impacts and conflicts}

Mining activity is commonly associated with major socio-environmental impacts as it significantly interferes in the territories in which it is installed. The socio-environmental impacts of mining are not limited to the surroundings of its operations, exposing diverse groups of stakeholders to risks generated by their activities, without the immediate chance of legal protection or compensation (ROCKSTRÖM, STEFFEN, NOONE et al., 2009). Stimulating the migratory process, conflict with other local economic activities and high consumption of natural resources are frequent examples cited in the literature. Rural areas tend to be impacted by air pollution, water contamination, deforestation and erosion. In urban regions, the effects include urban swelling, slums, increased violence, sexual exploitation and over-demand of public health, sanitation and security services (DAVIS and TILTON, 2005).

Increased community awareness of these socio-environmental impacts has also contributed to the increase in conflicts between mining activities and the local population that challenge the decision-making processes of sector managers (MCMAHON and REMY, 2003). In a study based on interviews with professionals in the areas of finance, legal and sustainability, in addition to empirical case studies, Franks, Davis, Bebbington et al. (2014) identified the most common conflicts that arise in mining areas (Figure 1).

Figure 1

\section{Conflicts in mining areas}

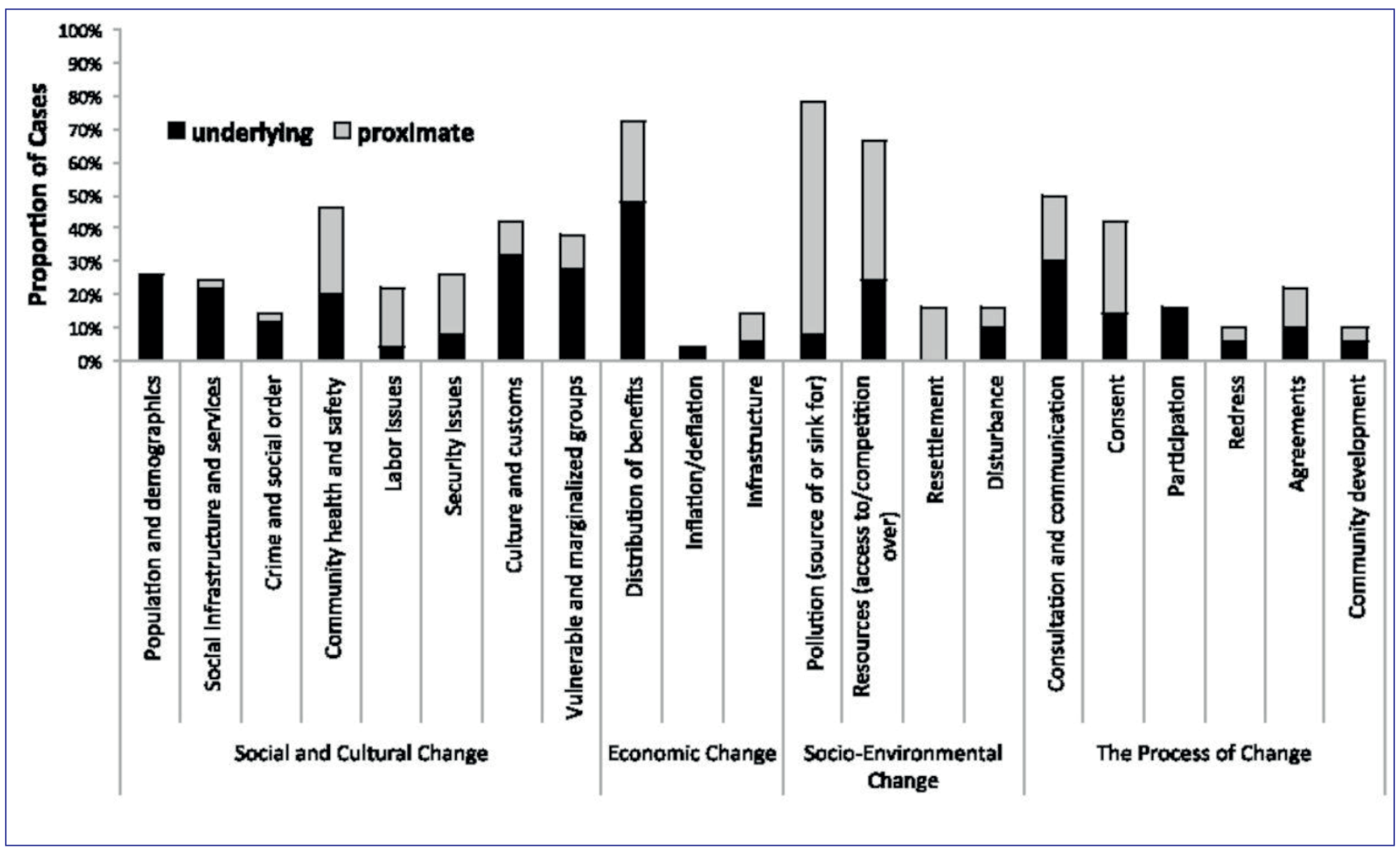

Source: Franks (2014). 
The research highlights the conflicts associated with pollution, the distribution of benefits, competition for resources, forms of communication and consultation and problems related to community health and safety. The authors conclude that mining companies tend to underestimate the financial impacts of social conflicts. As an example, a large mining project, with capital expenditure in the order of 3 billion USD and 5 billion USD, accumulated financial losses of 20 million USD per week due to production delays brought to present value because of a conflict. The authors argue, therefore, that social conflicts have the capacity to translate socio-environmental risks into business costs and decision-making, consisting of an important driver of change in corporate behavior.

Thus, the industry has sought to respond to the demands of different social actors from approaches that go beyond legal obligations. For Wilburn and Wilburn (2011), there is growing interest from mining companies to adopt SLO models in their CSR strategies.

\section{The construction of the social license in mining activities}

The approval and broad acceptance of society for companies to conduct their activities build the SLO, which cannot be granted by authorities, political structures or the legal system (SOLOMON, KATZ and LOVEL, 2008).

Different researchers point out that the term SLO was used for the first time by Jim Cooney, executive of Placer Dome, in a meeting promoted by the World Bank, in Washington, in 1997. Cooney argued that the "industry would have to act positively to recover its reputation and obtain a 'social license to operate' through a process that, starting with mines and individual projects, would create, over time, a public culture and profile for the mining industry" (THOMSON and BOUTILIER, 2011). For Prno and Slocombe (2012), the concept originated in mining studies in northern Canada. Since then, journalists, academics, companies and analysts have used SLO extensively as the idea that business meets tacit expectations from regulators, local communities and the general public in order to maintain their operations (GUNNINGHAM, KAGAN and THORTON, 2004).

Joyce and Thomson (2000) were the first to develop a theory based on the concept based on their experience providing consultancy to companies that lost SLO. With this theoretical concept known as the resource dependency theory, the authors conferred respectability on the SLO by incorporating it into the business strategy and competitiveness (BOUTILIER, BLACK and THOMSON, 2012).

Thomson and Boutilier (2011), in turn, systematized a process to earn and maintain the social license to operate. According to the authors, first, companies must identify all groups that may affect or are affected by the project. The reference method, or snowball, helps in this regard. Second, interviews with stakeholders should be conducted to hear their concerns, obtain SLO scores/ratings and develop a strategy for: a) addressing stakeholder concerns about the changes the company plans and practices; b) build agreement around shared goals for the community/network; and c) build support for the role of mining in community prosperity.

Thomson and Boutilier (2012) established four levels of obtaining the SLO: psychological retention, acceptance, approval and identification; and three boundary criteria that separate them, defined essentially by how the community perceives the company in three limits: legitimacy, credibility and trust, outlined in Figure 2. 
Figure 2

\section{The SLO model pyramid}

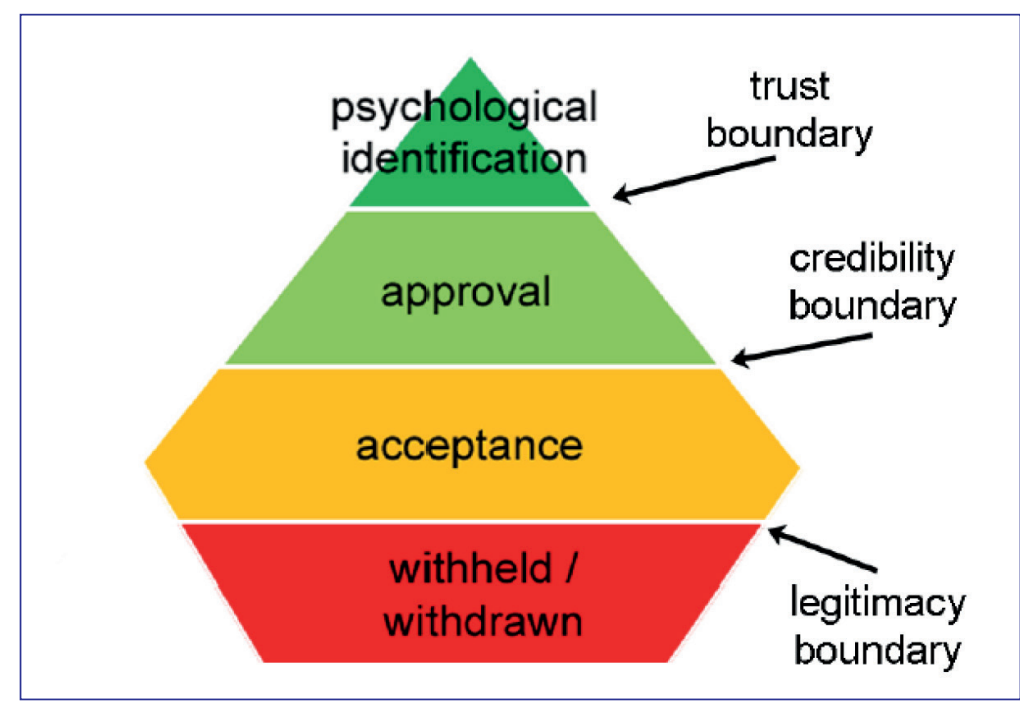

Source: Thomson and Boutilier (2011).

The authors define the essential components for each of the borders, starting with the legitimacy that consists of "acceptance of the general public and the relevant elite organizations of the right of an organization to exist and to exercise its activities in an elected manner" (THOMSON e BOUTILIER, 2011, p. 14). In the next phase, in order to gain credibility, transparency is essential and "results from the opening of information and decision making that demonstrates how the company is consistent in the way it treats different groups" (THOMSON e BOUTILIER, 2011, p. 15). To gain credibility, therefore, companies must deliver on short-term promises through participatory processes to identify community priorities that the company can help deliver. The authors also recommend that a third party verify the company's statements, as well as enabling the community to play a regulatory role in company activities through committees, for example.

According to the authors, when the company gains legitimacy and credibility, it is likely that the community will grant the social license, that represents the absence of socio-political risk and that the community can no longer be influenced by the "us-against-them rhetoric of anti-mining movements" (THOMSON and BOUTILIER, 2011, p. 18).

At a more advanced stage of trust, the community - of good will - becomes vulnerable to the company's actions, because the level of trust is such that it comes to believe that the company always acts for the interests of the community. The authors argue that when the community perceives the company as totally reliable, there is a feeling of co-ownership and the company becomes a member of the community's social network (THOMSON and BOUTILIER, 2011). However, it is important to remember that none of these stages is permanent, and even in a situation of psychological identification, the loss of social license can occur. Therefore, the SLO should be thought of as a process of continuous negotiation instead of the conventional logic of a legal contract with well-defined clauses and actions between the parties involved (FRANKS and COHEN, 2012).

In addition to the development of models for SLO, research has also advanced to criticize the effectiveness of this model. According McMahom and Remy (2003), in an ideal situation, the community surrounding the project, the central government and the mining company maintain a permanent dialogue to facilitate the design and implementation of a local and regional development plan. However, based on studies on the relationship of mining companies with communities in Chile, Peru and Ecuador, the researchers noted that companies typically negotiate with the central government and the community separately. This practice, called by the authors "triangle of the sides", is common in Latin American countries, where the central government has a fundamental role in the previous establishment of the legal and fiscal regime, environmental regulations and major infrastructure projects, to shortly afterwards grant the license to explore the mine. 
Schneider and Scherer (2015), in turn, they highlight that, in these circumstances, more and more stakeholders are individually exposed to the risks and costs resulting from the companies' businesses in cases where the regulatory power is unable to mitigate or socialize these risks.

In order to deal with this weakness, scholars have made recommendations for obtaining and maintaining the SLO, which include the need for communication before and after the implementation of the project, transparency in the dissemination of information, development of conflict resolution mechanisms and culturally appropriate decision-making processes (PRNO, 2013).

Joyce and Thomson (2000) pointed out as key factors of the SLO: a) consulting the community extensively and ensure that it is well informed not only about the socio-environmental impact assessment, but also during the permission process; and b) considering a model of constructive engagement, in which multiple parties work together to achieve common goals.

A survey conducted in January 2005 with participants in the BC and Yukon Chamber of Mines Cordilleran Round-Up Conference pointed out the three most frequent responses on how to obtain a SLO: a) maintain a positive corporate reputation; b) understand the culture, language and history of the groups; and c) ensure open communication between all stakeholders (NELSEN and SCOBLE, 2006).

From comparative case studies of four mines in the United States, Papua New Guinea, Canada and Peru, Prno (2013) identified five key factors related to maintaining SLO: a) the context is key, with no room for generalizations, since each mine is unique for its social, environmental, cultural and economic characteristics; b) social license is built on relationships; c) sustainability is a dominant concern for communities; d) the generation of benefits at the local level and public participation play a crucial role; e) adaptability is necessary to deal with the complexity. According to the author, these factors together can serve as "guiding principles" for the maintenance of SLO by the mining industry.

Moffat and Zhang (2014) point to trust as a central element in a SLO model, representing the mechanism by which the perception of the impacts of mining operations is mixed with the experiences and perceptions of justice of the processes related to the acceptance and approval of the operation of a mine. Zhang, Moffat, Lacey et al. (2015) point out three main elements that affect public confidence in the mining sector and, therefore, the acceptance of its activities on a national scale: a) fair distribution of mining benefits; b) fair procedures in interactions between the mining sector and society; c) confidence in governance agreements around mining activity. They conclude that, in order to achieve a more sustainable mining practice, in which social conflict is minimized and benefits extended, both mining companies and governments need to revise their methods of engaging citizens to build trust in their relationships.

\section{METHODOLOGY}

As it is a recent phenomenon in the literature, we opted for a qualitative approach of an exploratory and interpretative character, and the research strategy was to conduct a case study. One of the important phases of applying this technique is the appropriate selection of the case study. For Eisenhardt (1989), the uniqueness of the case allows us to build hypotheses on topics that have been little researched.

The scale of Samarco's tragedy is unprecedented on the world stage. The mud sea covered $663 \mathrm{~km}$, from the Fundão dam, located near the city of Mariana, up to Foz do Rio Doce, with the cost of recovering the impacted ecosystems estimated at 20 billion USD (FERNANDES, GOULART, RANIERI et al., 2016). For research purposes, the analysis unit was limited to the Alto Rio Doce, region where the dam broke out and the most rural among the affected municipalities.

Data collection techniques included document analysis and interviews. Such analysis was divided into two phases. In the first phase, we focus was on available public documents, including reports generated by public and non-governmental organizations (NGOs), seeking the history of the licensing, construction and operation of the Fundão dam. We complemented the documentary analysis with the reading of the sustainability reports, from 2005 to 2014, with the objective of identifying also in this material elements that were related to some of the main categories discussed in the literature review associated with the construction of the SLO, like transparency and dialogue. The second source of data collection consisted of conducting semi-structured interviews with multiple stakeholders. Seventeen interviews were conducted, including residents (12), representative of 
the town hall (1), representative of the Public Ministry (1), representative of the Archdiocese (1), Samarco representative (1) and representative of organized civil society (1). The interviews, as well as the field visit, were concentrated in the Bento Rodrigues district, in Mariana, and the municipality of Barra Longa. The interviews included questions related to investment in communities, communication channels, dialogue and transparency, risks and management of socio-environmental impacts, and company actions after the tragedy.

We opted for content analysis as a strategy, that proved to be adequate for the study in question, because it allows the decomposition of the speech and the identification of units of analysis or groups of representations for a categorization of the phenomena, when then it becomes possible to reconstruct meanings that present a deeper understanding of the studied group's interpretation of reality (SILVA, GOBBI and SIMÃO, 2011). For that purpose, we used a content analysis by categorization, seeking to establish equivalence relations with the elements considered essential in the SLO models necessary to ensure the legitimacy of mining projects. The analytical categories were based on the literature survey as shown in Box 1 below.

\section{Box 1}

\section{Survey in the literature}

\begin{tabular}{|c|l|}
\hline \multicolumn{1}{|c|}{ Categories } & \multicolumn{1}{|c|}{ Reference } \\
\hline Trust & Moffat and Zhang (2013); Thomson and Boutilier (2011) \\
\hline Dialogue and consultation & Joyce and Thomson (2000); McMahon and Remy (2003) \\
\hline Transparency & Prno (2013) \\
\hline Acceptance & Thomson and Boutilier (2011) \\
\hline Risk & Schneider and Scherer (2013) \\
\hline Disclosure of information & Prno (2013) \\
\hline Reputation & Nelsen and Scoble (2006) \\
\hline
\end{tabular}

Source: Elaborated by the authors.

\section{RESULTS}

\section{Economic and political situation of the tragedy}

According to Milanez, Santos, Wanderley et al. (2015), between 2003 and 2013, global ore imports jumped from 38 billion USD to 277 billion USD (an increase of 630\%). Brazil was one of the most benefited countries in this period, ranking second in global exports of minerals, accounting for $14.3 \%$ of exports of this good worldwide. Over these years, Brazil's economic dependence on the mining and exporting sector has deepened. In the same period, the share of ores in the country's exports increased from $5 \%$ to $14.5 \%$, with iron ore corresponding to $92.6 \%$ of this total. Samarco can be identified as an icon of this model, which was consolidated in the 1970s, consisting of a mine-pipeline-pelletizing-port complex whose main function was to supply the global market with semi-transformed natural goods extracted in Brazil.

However, the ore market in general, and iron ore in particular, is characterized by a cyclical character. Based on data provided by World Bank about ore commodity prices, our analysis showed a fluctuation from a USD 32 threshold (Jan./2003), the price of a ton of iron ore peaked at USD 196 (Apr./2008) and, starting in 2011, it began a downward trend, reaching USD 53 (Oct./2015) . 
Figure 3

International iron ore price

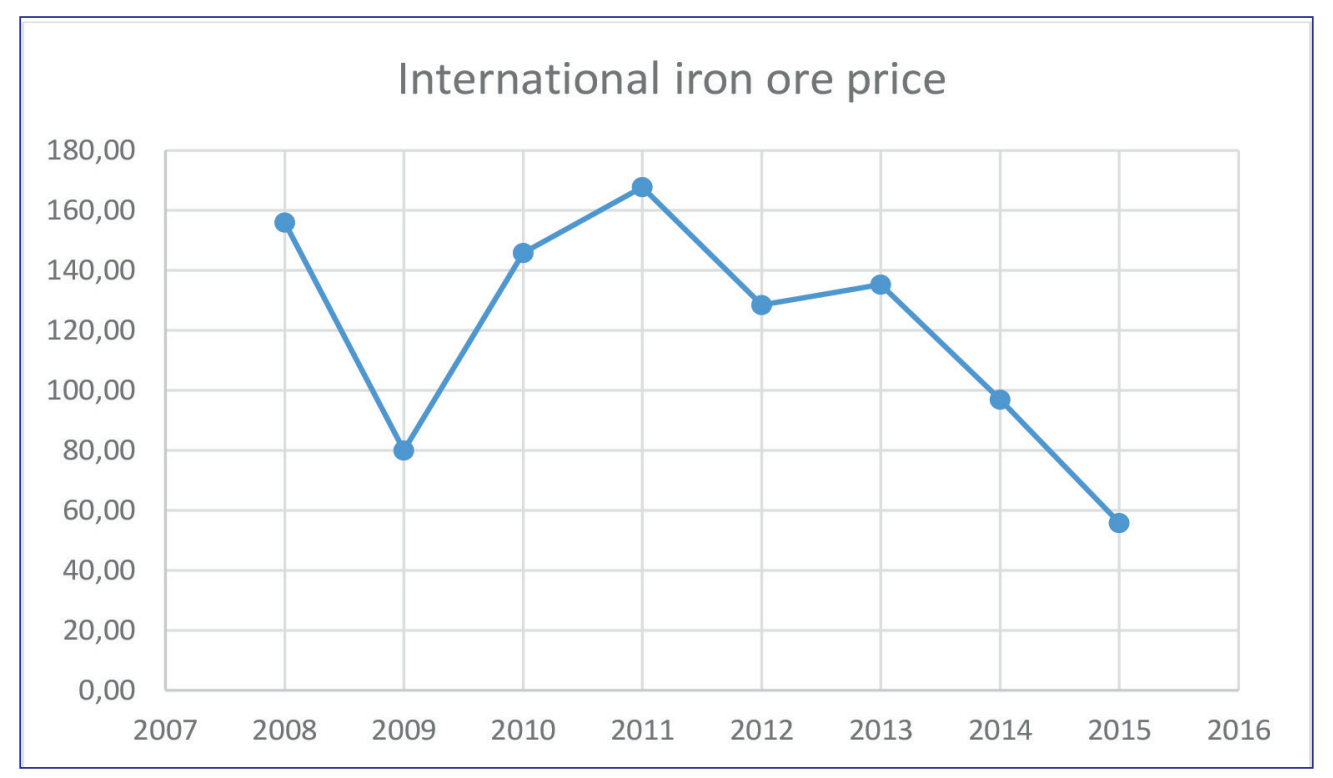

Source: Lopes (2017).

For Milanez, Santos, Wanderley et al. (2015), understanding this dynamic is important to understand the structural character of the Fundão dam rupture. Davies and Martin (2009) argue there is an increase in the occurrence of tailings dam ruptures during the recessive process of ore price cycles. According to the authors, the causes for this behavior are several. It is worth noting the rush to obtain licensing in the period of high prices, leading to the use of inappropriate technologies and the choice of unsuitable locations for the installation of projects; pressure on environmental agencies for speedy licensing, resulting in incomplete assessments of project risks and impacts; and intensification of production or pressure to reduce costs from the moment when prices return to the usual levels.

In the specific case of Samarco, all these elements can be observed, reinforcing the test by Davies and Martin (2009). The company's installation in the Mariana region took place in the 1970s, coinciding with the resumption of mining activity in Minas Gerais with the new exploration cycle of iron ore. The 1970s were marked by the implementation of major mining projects and foreign investments, considering that the new 1967 Mineral Code allowed foreign capital to participate in mining exploration projects. Samarco's installation coincides with the period when mining was reintroduced in the Mariana region after a period of economic decline since the end of the first gold mining cycle. The prospect of generating employment and income made the company win the approval of the authorities and the local population. Milanez, Santos, Wanderley et al. (2015) argue that this characteristic, added to the company's "merchandising" and socio-institutional investment actions, stimulated the collusion of local, regional authorities and the community in general with possible negative impacts generated by the company in the territory.

In the case of the Fundão dam, problems were already identified at the stage of choosing the location of the dam. The environmental impact study presented two alternatives that would imply lower risks for nearby communities, as Bento Rodrigues. Milanez, Santos, Wanderley et al. (2015) show that the decision to install the Fundão dam considered only the economic variable. In addition, after the tragedy, a report prepared by a panel of independent experts, hired by shareholders Vale and BHP Billiton, Samarco's parent companies pointed out incidents involving the dam since 2009 (LOPES, 2017). Analysis of research documents from Task Force Rio Doce 263, carried out by the Federal Public Ministry of the Attorney's Office in the States of Minas Gerais and Espírito Santo, revealed that the risks to the dam system at the Fundão complex were the subject of the board of directors meeting on August 10, 2011. On that occasion, the conclusions of a report by the Independent Tailing Review Board (ITRB) were presented, that identified the insufficiency of the internal drainage of Fundão, resulting in 
saturation of the slope downstream of Fundão with the risk of its rupture. The ITRB consisted of an external, independent body, formed by national and international experts, and control within Samarco's management.

In addition, the ITRB also drew attention to the need for Samarco to pay greater attention to the downstream communities in relation to emergency actions. In view of what was exposed by the ITRB, Samarco's board of directors manifested itself at the meeting: "The Council took note of the information and stressed that, after security, cost reduction should be the main focus of management" (BRASIL, 2016, p. 52).

However, according to the Federal Public Ministry (MPF), Samarco hired the company VOGBR Recursos Hídricos \& Geotecnia LTDA to prepare the report on the stability conditions of the Fundão dam. In 2015, VOGBR issued the declaration of stability of the dam, omitting relevant data, as the piezometric reading of the installed instruments, precisely in the retreat of the dam's axis. The aforementioned company, even knowing the various problems presented at the dam and all the risk situations arising, declared the safety of the structure, having full knowledge of its responsibilities as a legal entity responsible for said report, focusing on the crime provided for in art. 69-A, § 2ㅇ, of Law $n=9.605 / 95$, as the MPF investigation concluded (BRASIL, 2016, p. 264).

For the Public Ministry (MP) of Minas Gerais, Samarco led environmental agencies to error for omitting information on the disposal of Vale's ores in Fundão. The mining company would also have omitted operating conditions when requesting the revalidation of the dam's operating license. The prosecution filed a complaint that Samarco defrauded documents by requesting licensing for the dam. According to the MP, the Fundão dam did not have an environmental license to receive waste from Vale, parent company of Samarco together with BHP Billiton. According to the Federal Police (FP), $28 \%$ of the waste thrown in Fundão in 2014 corresponded to Vale. The MP also denounced that the works carried out in the place where the dam broke were not authorized by the competent agency, the State Environment Foundation (FEAM) (COISSI and BRAGA, 2016).

\section{The contradictions in sustainability reports and interviews}

Considering the documents analyzed regarding the history of the dam rupture, the first category analyzed was that of risks, especially with regard to the dam. References went from 20 mentions in 2006 to 44 in 2014, occupying the 44th position among the most frequent words of the 2014 edition. At the same time, the reports favor information that would indicate the safety of the processes in order to mitigate problems due to accidents. The company reports in the 2014 sustainability report that a simulation is carried out to verify actions, behaviors, procedures and resources in emergency situations. Cites studies aimed at reusing discarded materials and filtering waste, an investment area within the eco-efficiency and innovation pillar of its socio-institutional development program. This is seen as an indication that the generation of waste and dependence on the dam model was a concern.

From the perspective of the security of our operations, we have an Emergency Action Plan (EAP) for the dams, which addresses the operation of waste disposal structures and possible anomalies or emergency situations. Based on this document, which meets the legal requirements on dam management, in 2013, we applied 1,356 hours of training to employees directly or indirectly involved in activities (SAMARCO, 2013, p. 75).

These efforts, however, were not the subject of dialogue with the surrounding communities, as can be seen later in the analysis of the interviews. Nor is there evidence that the procedures mentioned in the context of the EAP of the dams have been effectively implemented in view of the collapse of the Fundão dam, including relief from the regulatory framework for dams that provides for the installation of an alert system and the availability of trained teams to assist communities in emergencies. Interesting to note that the word security occupies less and less space in the report. If in 2005 the word appears 104 times, in 2014 it is mentioned only 39 times. It is also interesting to note that the loss of importance of the word safety occurs in parallel with a period in which the risks of accidents at work increase. From 2008 to 2014, we found in the reports that the accident rate doubled, jumping from 0.61 to 1.27. It is important to highlight that since 2011 Samarco had been working with increasingly reduced prices of iron ore in the international market.

Direct mentions were also sought to Bento Rodrigues, since he was the closest community to the dam, and, as demonstrated in the documentary analysis, the most vulnerable in the event of a break. It is noticed that the presence of Bento Rodrigues, who was already not very expressive, disappears from reports as of 2009, with no further direct 
mention of the district in publications from that year. The few quotes found between 2005 and 2008 refer to one-off investments, as contributions to the reform of the municipality's church and investments in the association of residents and local producers.

Program aimed at improving the quality of life of the Bento Rodrigues community in Mariana (MG), from actions of environmental education, training of leaders and strengthening of the agribusiness. In 2005, a water treatment plant was built in the municipality. In addition, ophthalmic treatments and glasses were donated to the community. Investment: 7.2 mil. BRL (SAMARCO, 2005, p. 129).

If the issue of operational risks spoke little with the reality pointed out in the record presented of the disruption, an evolution of the reputational issue is found in the reports. The evidence in this regard can be observed as the reputation issue grows in importance in the company's report. While, in 2005, there was no mention of reputation, in 2014 these citations reach 30. In the 2011 report, the company mentions "Samarco's Reputation Platform", unfolding of the research carried out with its stakeholders applying the RepTrak ${ }^{\mathrm{TM}}$ Deep Dive Methodology, of the Reputation Institute, the result of which indicated that Samarco had a "strong" reputation among its stakeholders. According to the company, this study aimed to point out "the opportunities to positively impact reputation and the risks that must be managed" (SAMARCO, 2011, p. 31).

In general, citations to consultation, dialogue and transparency processes are not prevalent. In the 2005 publication, there is no evidence of stakeholder consultation practices, and the word "dialogue" appears only 11 times, not even appearing among the thousand most frequent words in the report.

In 2014, the picture is different, with 4 references to consultation with stakeholders and 22 to dialogue, but without more information about the specific activities carried out with each community, not being possible to identify those that happened in Bento Rodrigues. Even so, the content of the reports reinforces Samarco's transparency regarding the positive and negative impacts for the community.

Among the structured dialogue forums are meetings with the community; Samarco's Environmental Licenses Monitoring Forum (Speech, implemented in Espírito Santo); the Local Development Committees; Leadership meetings; and the Visiting Program. In these forums, we deal with negative and positive impacts, qualify and develop communities, we take information about the Company and listen to people (SAMARCO, 2014, p. 42).

When going through the analysis of the interviews, we found contradictions especially with regard to the information that reached the residents. The reports of the residents of Bento Rodrigues affected by the rupture of the dam show that the safety of the dam complex has always been a concern for them, due to the proximity of its location to the village. According to the residents' report, confirmed in an interview with the company's spokesman, the topic was frequently discussed with Samarco employees during their visits to the community.

It was a lady at my restaurant in 2010 saying she was hearing about a dam that was about to burst [...].So this dam was a problem, but they managed to get around. It had already raised a red flag, but they did not communicate it to us. They said it wasn't to communicate anything because they were in control of the situation. They already knew there was a problem (Resident of Bento Rodrigues).

Despite the perception of the unsafe conditions of the dam by the population, it is important to highlight that the residents of Bento Rodrigues trusted Samarco's information regarding the security of the process, repeated in several interviews. Thus, the concern with risk never materialized in a movement organized with force to counter the safety discourse of Samarco's processes and operations. The company continued to expand its activities in the municipality, contributing to Mariana's increasing dependence on mining activity, recognized by the interviewed Samarco representative. When the dam rupture materializes, the representative states that the emergency plan was triggered, as presented in the environmental licensing process, valued as one of its procedures for controlling environmental and social impacts, as reported in the sustainability reports. However, the company did not comply with the requirements of the National Dam Safety Plan (NDSP), which requires the installation of an audible alarm system and the provision of trained staff to advise communities in emergency situations. The company's action was limited to communicating the accident to the city hall and the civil defense of Mariana, whose 
teams arrived on the scene a few hours after the dam burst. In the absence of any official communication, of rescue teams or even instruction on how to act in emergency situations, residents intuitively took shelter in the upper part of the district. For the company representative, despite the magnitude of the socio-environmental impact, the residents' trust in Samarco, built over the years, was essential, to minimize conflicts and continue dialogue in these difficult times.

Despite the community's revolt, we managed to continue establishing a relationship of trust and building humanitarian response solutions together with community leaders. Three days later I was wearing the company's actual uniform there in the region. In other cases this would be unthinkable, the level of conflict, of violence, would be very high. The community realized that the company, despite everything that happened, was there wanting to solve, committing and seeking a solution to address the issues (Samarco's representative).

In the residents' statements, however, there is a very large drop in the degree of trust. The reason for this frustration revolves around the omission on the part of the mining company of the problems in the dam that had already been verified before its rupture - as demonstrated by the investigation of the task force set up by the MPF to investigate the causes of the tragedy, whose conclusions have been partly explained above.

Inside, in their area, they struggled so much for security, why didn't they care about us out here? If there was a risk, the first thing would be to communicate the community of Bento. It doesn't matter if [the dam] was going to burst or not, but at least they had to warn us. But they didn't even do that (Resident of Bento Rodrigues).

Other contradictory elements also draw the attention, such as the issue of assistance provided to those affected after the tragedy. The company representative said in an interview that his action went beyond legal requirements, citing measures that resulted from MP interventions as good practices.

We have implemented a humanitarian response process that went far beyond what the emergency plan established, I can tell you this because I designed the humanitarian response plan based on the best practices we found in the world for natural disasters and other actions (Samarco's representative).

The interviews with the authorities in Mariana, however, bring elements that relax this company's argumentative line. All the Prosecutor's actions on Human Rights of Mariana County are registered and present concrete evidence that guided the actions taken by the company to assist those affected.

Everything the company has done to date, all claims met, it did so much more through pressure from the prosecutor than through recognition itself or what it wanted to do (Priest of the Archdiocese of Mariana).

Also according to the prosecution of human rights of the MP of Minas Gerais, until some time Samarco fulfilled a large part of what was demanded in court, mainly the settlement of families in rented houses. However, the company failed to consider many people as affected: stopped delivering debit cards to people who depended on financial assistance and paying indemnity advances.

From a certain moment, when the prosecution was transferred to the federal court, Samarco took advantage of this moment to deny many rights to several affected in an absurd and unacceptable way (District Attorney).

It is also important to highlight that the degree of economic dependence of the territory in relation to Samarco ended up generating a movement in the short term for the resumption of the company's operations.

Fifteen days after the tragedy some people from Mariana were already on the street, asking for Samarco's return, it was very sad. [...]They want the company back but the company wants to return the same way, right? Then it returns the same way, soon it happens again (Resident of Bento Rodrigues). 
For the residents of Bento Rodrigues, this constituted a new impact on their lives, to the extent that solidarity at the time of the tragedy ended up being replaced by a negative view, in which those affected ended up being held responsible for the economic problems faced by the municipality.

\section{DISCUSSION OF RESULTS}

The Samarco case exposes the limitations of CSR models for situations involving communities with low social capital. The criticism by Hilson (2012), pointing out that the corporate CSR models conceived within the scope of developed economies, when applied in developing countries, represent a gray area that needs more research, it seems to find a fertile field in the Samarco case. The case presented corroborates the criticisms by Jenkins and Yakovleva (2006) on the mismatch between information made available in sustainability reports and companies' effective practices. The dam's operational problems, which have been showing signs since 2009, and its risks were excluded from reports that emphasized the safety of its processes and the organization's readiness to deal with emergency situations. Also considering that mining companies have an increasing interest in implementing their CSR through models such as the SLO (WILBURN and WILBURN, 2011), it can be inferred from the case study that the models by Thomson and Boutilier (2011) and Moffat and Zhang (2014) centered on relationships of trust may, in certain contexts, increase the vulnerability of communities surrounding mining projects. As stated by Thomson and Boutilier (2011), when the community perceives the company as totally trustworthy, there is a feeling of co-ownership, and the company becomes a member of the local social network. Psychological identification, considered by the authors as the highest degree of SLO, can be found in this case, worsening the situation of social vulnerability and economic dependence of local communities.

This research shows that the emphasis on maintaining corporate reputation, as proposed by Nelsen and Scoble (2006), was a priority in Samarco's actions in order to minimize risks of resistance to the project by the stakeholders. Investments in the area of socio-institutional development have not promoted the empowerment of communities in order to minimize the relationship of economic dependence. No evidence was identified from fieldwork that these criteria - when practiced by Samarco - were in fact consolidated. Indeed, there was no evidence that there were solid processes of consultation and local participation resulting from a tripartite dialogue between community, business and governments, as SLO scholars recommend. The company's legitimacy with the community was built due to the lack of knowledge of its effective practices, as in the case of the risk of the dam. Despite being a problem already identified in 2009, this was not passed on to the community, even with the request made by residents of Bento Rodrigues for clarification on the safety of the dam. To maintain the positive perception of the community and minimize concerns about the safety of its dams, the company used devices such as inviting representatives of Bento Rodrigues to visit another dam in its system, that of Santarém, as the interviews with those affected by Bento Rodrigues revealed. In this sense, the company's limited actions in the field of CSR, such as occasional investments in the community, contributed to the loss of critical capacity, configuring a situation of resignation. Thus, the perception of the community's risk on the dam did not materialize in clash actions against the company, Samarco's discourse of total process security prevails, repeating the contents made available in the reports.

In the case studied, this asymmetry of power, coupled with economic dependence, culminated in the pressure of part of the population for the return of Samarco's operation, which according to Milanez, Santos, Wanderley et al. (2015) which was added to the state and business efforts to treat the tragedy as a fatality and fit Samarco in the list of victims. 


\section{CONCLUSIONS}

Samarco's tragedy, considering its enormous environmental, social and economic impacts, implies challenges in the operationalization of CSR models developed in the contexts of developed countries. Returning to the research question proposed in this work, it is inferred that in a context marked by the low social capital of local communities, a high degree of economic dependence and social vulnerability, the CSR model implemented at Samarco, based on the availability of information in its sustainability reports and SLO criteria, demonstrated low effectiveness. Dialogue, transparency, consultation, risk management and local investments were frequently mentioned in the analyzed company documents. As a result, Samarco was considered a genuine member of the community's social network. However, the use of these strategies prioritized the monitoring of the perception of the company's image and reputation with its different stakeholders. Nor did investments in the area of socioinstitutional development promote the empowerment of communities to minimize the relationship of economic dependence or reduce social vulnerability. In addition, such levels of trust and economic dependence in the municipality have masked environmental, social and economic risks, increasing the vulnerability of the population and the local community.

Samarco's case also draws attention to the fact that conventional management models are not efficient for mitigating or limiting large risks that go beyond the boundaries of time and space, since they transcend the mere environmental assessment of the company itself or the licensing agency. In view of this, it would be up to society to endorse the approval of an economic activity that could cause damage of the dimension of the tragedy in question. However, the case presented shows the various challenges for the effectiveness of a democratic corporate governance model, in which the different community actors are heard and empowered in the decision-making processes that concern their future. In this context, the question of how to empower the community and ensure a strong institutional environment seems to be the key to achieving a complete and effective CSR process.

Another finding is that some good practices have hidden or diverted attention to serious management problems, in view of the non-compliance with basic requirements of the regulatory framework of dams such as the installation of an alert system and the availability of trained teams to assist communities in cases of emergency. In addition, we observed elements in the sustainability reports pointing out that efforts related to CSR and SLO maintenance were more focused on obtaining a positive reputation to the detriment of the other factors raised in the literature. This may have contributed to a situation of greater vulnerability and even to cooptation of the surrounding communities, bearing in mind that there was also no evidence of transparent communication regarding the risks inherent to the company's activity.

Although this study presents the limitations inherent to research focused on a single case, it is believed that the results reinforce the need to deepen investigations related to the weaknesses between discourse and practice of CSR initiatives in the Brazilian reality. A big question that arises is whether the dimension of this tragedy will represent a game changer in the current management models in the mining sector that insist on maintaining social and environmental variables as marginal issues for decision making. The mining sector, however, has been pushing for a more flexible licensing process, as occurred in the state of Minas Gerais, where changes in environmental licensing met the demands of the mineral sector, which was also pressing the state government to accelerate the licensing process. Such positioning goes in the opposite direction of the potential lessons learned from the tragedy in Mariana, both for companies and for the public sector, perpetuating a situation of vulnerability in the territories where numerous mining enterprises are located. 


\section{REFERENCES}

ANSELL, C.; GASH, A. Collaborative governance in theory and practice. Journal of Public Administration Research and Theory, n. 8, p. 543557, 2007.

BANCO MUNDIAL. Commodity markets. 2015. Available at: <http:// www.worldbank.org/en/research/commodity-markets>. Accessed on: Jan. 05, 2017.

BECK, U. Sociedade de risco: rumo a uma outra modernidade. 2. ed. São Paulo: Editora 34, 2011.

BOUTILIER, R. G.; BLACK, L.; THOMSON, I. From metaphor to management tool: how the social license to operate can stabilise the socio-political environment for business. In: INTERNATIONAL MINE MANAGEMENT, 2012, Melbourne. Proceedings... Melbourne: Internacional Mine Management, 2012. p. 227-237.

BRASIL. Ministério Público Federal. Procuradoria da República nos Estados de Minas Gerais e Espírito Santo - Força-Tarefa Rio Doce. Procedimento investigatório criminal (PIC) MPF n.e 1.22.000.000003/2016-04. Brasília: MPF, 2016. Available at: <http:// www.mpf.mp.br/mg/sala-de-imprensa/docs/denuncia-samarco >. Accessed on: Jan. 05, 2017.

COISSI, J.; BRAGA, F. Lama de Mariana chega ao litoral do ES com protesto de moradores. Folha de S. Paulo, São Paulo, 21 nov. 2015. Available at: <http://www1.folha.uol.com.br/cotidiano/2015/11/1709414lama-de-mariana-chega-ao-mar-do-es-com-protesto-de-moradores. shtml>. Accessed on: Jan. 20, 2016.

DAVIS, G. A.; TILTON, J. E. The resource curse. Natural Resources Forum, v. 29, n. 3, p. 233-242, 2005. Available at: <https://onlinelibrary. wiley.com/doi/full/10.1111/j.1477-8947.2005.00133.x>. Accessed on: Mar. 31, 2018.

DAVIES, M.; MARTIN, T. Mining market cycles and tailing dams incidents. In: INTERNATIONAL CONFERENCE ON TAILINGS AND MINE WASTE, 13, Banff. Proceedings... Banff: AB, 2009.

EISENHARDT, K. M. Building teories from case study research. Academy of Management Review, 1989.

O ESTADO DE S. PAULO. ANEFAC premia vinte empresas com troféu transparência. Agência Estado, São Paulo, 18 jul. 2013. Available at: <https://economia.estadao.com.br/noticias/negocios, anefacpremia-20-empresas-com-trofeu-transparencia,159532e>. Accessed on: Dec. 19, 2017.

FERNANDES et al. Deep in the mud: ecological and social economic impacts of the dan breach in Mariana, Brazil. Brazilian Journal of Nature Conservation, v. 14, p. 35-45, 2016.

FRANKS, D. M. et al. Conflict translates environmental and social risk into business costs. National Academy of Sciences of the United States of America, v. 111, n. 21, p. 7576-81, 2014. Available at: <http://www.pnas.org/content/111/21/7576.short>. Accessed on: Mar. 31, 2018.

FRANKS, D. M.; COHEN, T. Social license to operate. Constructive technology assessment within a mineral reserch and development institution. Technological Forecasting and Social Change, v. 79, n. 7, p. 1229-1240, 2012.
GUNNINGHAM, N.; KAGAN, R. A.; THORNTON, D. Social license and environmental protection: why businesses go beyond compliance. Law \& Social Inquiry, v. 29, n. 2, p. 307-341, 2004.

HILSON, G. Corporate social responsibility in the extrative industries: experiences from development countries. Resources Policy, v. 37, p. 131-137, 2012.

HOWARD-GRENVILLE, J.; NASH, J.; COGLIANESE, C. Constructing the license to operate: internal factors and their influence on corporate environmental decisions. Law and Policy, v. 30, n. 1, p. 73-107, 2008.

IBRAM - INSTITUTO BRASILEIRO DE MINERAÇÃO. Informações sobre a economia mineral brasileira 2015. Brasília: IBRAM, out. 205. Available at: <http://www.ibram.org.br/sites/1300/1382/00005957. pdf>. Accessed on: Mar. 31, 2018.

JENKINS, H.; YAKOVLEVA, N. Corporate social responsibility in the mining industry: exploring trends in social enviromental disclosure. Journal of Cleaner Production, v. 14, p. 271-284, 2006.

JOYCE, S.; THOMSON, I. Earning a social licence to operate: social acceptability and resource development in Latin America social risk. Latin America sources of social risk. The Canadian Mining and Metallurgical Bulletin, v. 93, n. 1037, p. 1-9, 2000.

KNOKE, D. The political economies of associations. Research. Political Sociology, v. 1, n. 1, p. 211-242, 1985.

LOPES, J. A licença social para operar na atividade mineradora no Brasil: o caso Samarco e a gestão de riscos ampliados. 2017. 112p. Dissertation (Master Degree in Administration) - Centro Universitário da FEl, 2017.

MCMAHON, G.; REMY, F. Principales observaciones y recomendaciones: una síntesis de los estudios de caso. Grandes minas y la comunidad, p. 1-38, 2003.

MCWILLIAN, A.; SIEGEL, D. Corporate social responsibility: a theory of the firm P. Academy Management Journal, v. 26, p. 117-127, 2001.

MILANEZ, B. et al. Antes fosse mais leve a carga: avaliação dos aspectos econômicos, políticos e sociais do desastre da Samarco/Vale/BHP em Mariana (MG). [S. I.: s. n.], 2015. Mimeo. Available at: <http:// www.uffi.br/poemas/files/2014/07/PoEMAS-2015-Antes-fosse-maisleve-a-carga-vers\%C3\%A3o-final.pdf>. Accessed on: Mar. 31, 2018.

MOFFAT, K.; ZHANG, A. The paths to social licence to operate: an integrative model explaining community acceptance of mining. Resources Policy, v. 39, n. 1, p. 61-70, 2014.

NELSEN, J.; SCOBLE, M. Social license to operate mines: issues of situational analysis and process. Department of Mining Engineering, University of British Columbia, Vancouver, Feb., 2006.

PRNO, J. An analysis of factors leading to the establishment of a social licence to operate in the mining industry. Resources Policy, v. 38, n. 4, p. 577-590, 2013.

PRNO, J.; SLOCOMBE, D. S. Exploring the origins of "social license to operate" in the mining sector: Perspectives from governance and sustainability theories. Resources Policy, v. 37, n. 3, p. 346-357, 2012. 
ROCKSTRÖM, J. et al. A safe operating space for humanity. Nature, v. 461, n. 7263, p. 472-475, 2009.

SAMARCO. Relatório de Sustentabilidade 2005. [S.I.]: Samarco, 2005. Available at: <https://www.samarco.com/wp-content/ uploads/2016/08/2005-Relatorio-Anual-de-Sustentabilidade.pdf>. Accessed on: May 01, 2017.

SAMARCO. Relatório de Sustentabilidade 2011. [S.I.]: Samarco, 2011. Available at: <https://www.samarco.com/wp-content/ uploads/2016/08/2011-Relatorio-Anual-de-Sustentabilidade.pdf>. Accessed on: May 01, 2017.

SAMARCO. Relatório de Sustentabilidade 2012. [S.I.]: Samarco, 2012. Available at: <https://www.samarco.com/wp-content/ uploads/2016/08/2012-Relatorio-Anual-de-Sustentabilidade.pdf>. Accessed on: May 01, 2017.

SAMARCO. Relatório de Sustentabilidade 2013. [S.I.]: Samarco, 2013. Available at: <https://www.samarco.com/wp-content/ uploads/2016/08/2013-Relatorio-Anual-de-Sustentabilidade.pdf>. Accessed on: May 01, 2017.

SAMARCO. Relatório de Sustentabilidade 2014. [S.I.]: Samarco, 2014. Available at: <http://www.samarco.com/wp-content/ uploads/2016/08/2014-Relatorio-Anual-de-Sustentabilidade.pdf>. Accessed on: May 01, 2017.

SANTIAGO, A. L. F. Licença social para operar relacionamento da empresa com a comunidade local: critérios de influência para a concessão da LSO. Um estudo de caso da mineração brasileira. 2016. 323f. Thesis (Doctor Degree in Administration) - Centro Universitário FEl, São Paulo, 2016.

SANTIAGO, A. L. F.; DEMAJOROVIC, J. Social license to operate: a case study from a Brazilian mining industry. Latin American Journal of Management for Sustainable Development, v. 3, p. 19-34, 2016.

SCHNEIDER, A.; SCHERER, A. G. Corporate governance in a risk society. Journal of Business Ethics, n. 126, p. 309-323, 2015. Available at: <https://link.springer.com/article/10.1007/s10551-013-1943-4>. Accessed on: Mar. 31, 2018.

SILVA, C. R.; GOBBI, B. C.; SIMÃO, A. O uso da análise de conteúdo como uma ferramenta para a pesquisa qualitativa: descrição e aplicação do método. Organizações Rurais \& Agroindustriais, v. 7, n. 1, 2011

SOLOMON, F.; KATZ, E.; LOVEL, R. Social dimensions of mining: research, policy and practice challenges for the minerals industry in Australia. Resources Policy, v. 33, n. 3, p. 142-149, 2008.

THOMSON, I.; BOUTILIER, R. G. Social license to operate. In: DARLING P. (Ed.). SME Mining engineering handbook. [S. I.: s. n.], 2011.

WILBURN, K. M.; WILBURN, R. Achieving social license to operate using stakeholder theory. Journal of International Business Ethics, v. 4, n. 2, 2011.

ZHANG, A. et al. Understanding the social licence to operate of mining at the national scale: a comparative study of Australia, China and Chile. Journal of Cleaner Production, v. 108, p. 1063-1072, 2015.

Juliana Campos Lopes

ORCID: https://orcid.org/0000-0003-4781-723X

Master in Administration, Graduate Program in Administration Centro Universitário FEI, São Paulo - SP, Brazil. E-mail: jcl.press@gmail.com

Jacques Demajorovic

ORCID: https://orcid.org/0000-0001-6131-8790

PhD in Education, Professor of the Graduate Program in Administration, Centro Universitário FEI, São Paulo - SP, Brazil. E-mail: jacquesd@fei.edu.br 